\title{
Genetics of temporal lobe epilepsy
}

\section{Vadlamudi, I E Scheffer, S F Berkovic}

Our traditional understanding is that TLE is an acquired condition, but only now are we beginning to understand the extent of genetic involvement

Jo

the second half of the 19th century,

ohn Hughlings Jackson proposed the

concept of partial epilepsy, including "uncinate seizures", based on clinicopathological observations from patients with structural lesions and further supported by pioneering brain surgery. ${ }^{12}$

With the discovery of EEG in the early 20th century, the concepts of temporal lobe epilepsy (TLE) were further elucidated. Gibbs et al ${ }^{3}$ described widespread slow activity during "psychomotor attacks"; they proposed a diffuse underlying cerebral disturbance, which was not in line with Jackson's observations. Jasper and Kershman ${ }^{4}$ then described focal temporal sharp waves in patients they diagnosed with "temporal lobe seizures". By the middle of the 20th century, the term TLE was widely utilised and much of the subsequent understanding of this disorder was based on pre-surgical studies of intractable cases. Traditionally, TLE has been considered to be an acquired disorder secondary to lesions such as hippocampal sclerosis, tumours, trauma, vascular malformations, and neuronal migration disorders. ${ }^{5}$

Falconer et al, however, studied the aetiology of TLE in 110 refractory cases and demonstrated $95 \%$ of cases had underlying cerebral pathology, but also astutely stated, "these lesions, however may develop on a soil already predisposed to convulsions" ${ }^{\prime 6}$ In the past 20 years, what is becoming more evident is this evolving key role of genetics in TLE.

\section{AUTOSOMAL DOMINANT PARTIAL EPILEPSY WITH AUDITORY FEATURES}

In 1995, Ottman et al described partial epilepsy with auditory features linked to chromosome $10 \mathrm{q}^{7}$ and later termed the syndrome autosomal dominant partial epilepsy with auditory features (ADPEAF). ${ }^{8}$ Similar families mapping to the same region were described with prominent visual features or sensory dysphasia, all suggesting a lateral temporal origin. ${ }^{9}{ }^{10}$ ADPEAF is a benign syndrome with onset in the first to third decades of life, no abnormalities on
MRI, and no association with febrile seizures (table 1).

Debate as to whether the families with somewhat differing clinical features were due to the same gene was settled when Kalachikov et al ${ }^{11}$ identified mutations in the leucine rich, glioma inactivated 1 (LGIl) gene in five families with ADPEAF and mutations in this gene were also found in families with prominent visual or dysphasic features. LGIl mutations are not found in all families with ADPEAF, suggesting genetic heterogeneity. ${ }^{12}{ }^{13}$ Specificity of LGIl to ADPEAF has been confirmed by the absence of mutations in different TLE phenotypes (unpublished data, Berkovic et al).

LGIl was first described in glial tumours where it may be deleted or rearranged, but glial tumours do not occur with increased frequency in ADPEAF. It has been suggested that LGIl has a role in neuronal migration or cortical organisation. ${ }^{11}$ Given that the majority of LGIl mutations cause protein truncation, loss of function is the likely underlying mechanism. ${ }^{11}{ }^{14}$ All prior genes that have been discovered for idiopathic epilepsies have been associated with ion channels. ${ }^{15}$ This discovery suggests new neurobiological mechanisms for familial epilepsies.

\section{FAMILIAL MESIAL TEMPORAL LOBE EPILEPSY}

In 1994, we described familial mesial temporal lobe epilepsy (FMTLE) as a benign syndrome with onset in the second to fifth decades of life, no temporal lobe or hippocampal abnormalities on MRI, and no association with febrile seizures (table 1 ). ${ }^{16}{ }^{17}$ The nature of the aura, with prominent psychic and autonomic features, suggested mesial temporal origin. The commonest symptom was intense déjà vu; in some cases epilepsy had not been diagnosed and the intense déjà vu was regarded as "normal". Inheritance is consistent with autosomal dominance with reduced penetrance, but no very large pedigrees have been reported and the disorder is yet to be mapped. The clinical features and good prognosis of FMTLE have since been described by others investigating idiopathic TLE. ${ }^{18-21}$

FMTLE, hippocampal sclerosis, and febrile seizures

The initial descriptions of ADPEAF and more common syndrome of FMTLE led to the idea of a clinicoradiological distinction between these benign TLE syndromes, without preceding febrile seizures or hippocampal sclerosis, and patients with severe "sporadic" TLE with hippocampal sclerosis and frequently preceding febrile seizures. Subsequently, it has become apparent that the relationship between FMTLE syndromes, hippocampal sclerosis, and febrile seizures is far more complex.

\section{FMTLE often associated with} hippocampal sclerosis

Heterogeneity of FMTLE was shown when multiple TLE families with more severe syndromes were described with onset in the first to third decades of life, frequent hippocampal sclerosis, and a variable association with febrile seizures (table 1). ${ }^{22}{ }^{23}$ Inheritance in some families is autosomal dominant, but mapping studies are yet to be reported.

These new data add to the puzzle of the aetiology of hippocampal sclerosis. There remains debate as to whether hippocampal sclerosis is the consequence of an early childhood injury (such as prolonged febrile seizures and encephalitis), ${ }^{24}$ a consequence of ongoing seizures, ${ }^{25}$ or an early developmental lesion. ${ }^{26}$ Genetic factors have been implicated since Falconer's pioneering studies and these large families with hippocampal pathology suggests a major genetic component to its aetiology, at least in certain cases.

\section{FMTLE often associated with} febrile seizures

Two large families and some smaller kindred's have been described with many individuals with both TLE and febrile seizures. The TLE syndrome begins in the first to second decades of life, there are no temporal lobe or hippocampal abnormalities on MRI and the course is benign (table 1). ${ }^{27-29}$ Digenic inheritance was suggested for the French family, one locus with significant linkage at chromosomes 18qter and one with supportive linkage at $1 \mathrm{q} 25-\mathrm{q} 31 .^{28}$ Linkage was not found in the Belgian family to known candidate loci. $^{27}$

Febrile seizures often associated with mesial TLE

It is more common to find families where there are multiple individuals with febrile seizures and a few with TLE. A large 
Table 1 Familial temporal lobe epilepsy (TLE) subtypes

\begin{tabular}{|c|c|c|c|c|c|c|}
\hline \multirow[b]{2}{*}{ Syndrome } & \multirow[b]{2}{*}{ ADPEAF $^{7-11}$} & \multicolumn{3}{|c|}{ Familial mesial (FM) TLE syndromes* } & \multicolumn{2}{|c|}{$\begin{array}{l}\text { TLE in broader partial epilepsy syndromes } \\
\text { syndrome }\end{array}$} \\
\hline & & $\begin{array}{l}\text { FMTLE no HS no } \\
\text { FS }^{16-20}\end{array}$ & $\begin{array}{l}\text { FMTLE often HS } \\
+/- \text { FS }^{22} 23\end{array}$ & $\begin{array}{l}\text { FMTLE with FS } \\
\text { usually no } \mathrm{HS}^{27} 28\end{array}$ & FPEVF $^{32} 33$ & PEPS $^{34}$ \\
\hline Typical age of onset† & 8 years to 4 th decade & $\begin{array}{l}10 \text { years to } 4 \text { th } \\
\text { decade }\end{array}$ & $\begin{array}{l}1 \text { year to } 3 r d \\
\text { decade }\end{array}$ & $\begin{array}{l}1 \text { year to } 2 \text { nd } \\
\text { decade }\end{array}$ & 1 year to 4 th decade & 2 years to 2 nd decade \\
\hline Characteristic features & Auditory, sensory aura & $\begin{array}{l}\text { Psychic, autonomic } \\
\text { aura }\end{array}$ & & & $\begin{array}{l}\text { Seizures with different } \\
\text { focal origin in family } \\
\text { members }\end{array}$ & $\begin{array}{l}\text { Multiple seizure types } \\
\text { in the same individual }\end{array}$ \\
\hline EEG & Rare temporal discharges & $\begin{array}{l}\text { Rare temporal } \\
\text { discharges }\end{array}$ & $\begin{array}{l}\text { Frequent temporal } \\
\text { discharges }\end{array}$ & $\begin{array}{l}\text { Occasional } \\
\text { temporal } \\
\text { discharges }\end{array}$ & $\begin{array}{l}\text { Occasional temporal } \\
\text { discharges }\end{array}$ & $\begin{array}{l}\text { Frequent peri-central } \\
\text { spikes }\end{array}$ \\
\hline MRI & Normal & Normal & HS & Normal & Normal & Normal \\
\hline $\begin{array}{l}\text { Outcome } \\
\text { Linkage }\end{array}$ & $\begin{array}{l}\text { Generally benign } \\
10 q\end{array}$ & Generally benign & Offen refractory & $\begin{array}{l}\text { Variable } \\
18 q t, 1 q \text { (?) }\end{array}$ & $\begin{array}{l}\text { Variable } \\
22 q, 2 q \text { (?) }\end{array}$ & $\begin{array}{l}\text { Generally benign } \\
4 p\end{array}$ \\
\hline Genes & LGI1 & - & - & - & - & - \\
\hline
\end{tabular}

study of such families demonstrated a strong association between prolonged febrile seizures and hippocampal sclerosis. ${ }^{30}$ Another family has been described with generalised epilepsy with febrile seizures plus, with a few family members with TLE. ${ }^{31}$ The proband had TLE with hippocampal sclerosis. All affected family members had a sodium channel mutation (SCNIA).

\section{TLE AS PART OF DOMINANT PARTIAL EPILEPSY SYNDROMES}

Other familial partial epilepsies have recently been described that include seizures arising from the temporal lobe as part of their spectrum of clinical manifestations.

Familial partial epilepsy with variable foci (FPEVF) was first described by our group (in an Australian family) with onset in the first to third decades of life, heterogeneous seizures types including TLE within the same family, and without associated MRI abnormalities or febrile seizures (table 1). ${ }^{32}$ There was a suggestion of linkage to chromosome 2q. In 1999 a more definite linkage at chromosome 22q11-q12 was found in two large French-Canadian families with similar clinical features. ${ }^{33}$

Partial epilepsy with pericental spikes (PEPS) was described in a single Brazilian family as a generally benign syndrome with onset in the first to second decades of life, partial seizures including TLE, characteristic pericentral spikes on EEG, without associated MRI abnormalities or febrile seizures (table 1). ${ }^{34}$ Linkage was demonstrated to chromosome $4 \mathrm{pl} 15 .^{34}$

\section{SUSCEPTIBILITY GENES}

The syndromes described above appear to segregate major autosomal dominant genes; these are studied by linkage analysis, a robust technique depending on large families. Many patients with TLE do not have such a strong family history, yet genetic factors are likely to be involved to some extent. Such susceptibility genes have been studied by association studies. Association studies involve large numbers of sporadic cases to determine if there is significant association of epilepsy with a particular polymorphism within a gene.

Identifying susceptibility genes remains challenging, as there is no single locus of large effect, but rather multiple loci probably exist. ${ }^{35}$ Determination of such genes by association studies has many methodological problems and replication of the initial observation is often negative. Methodological issues include power of the study, false positives and differing ethnic background. Currently four polymorphisms have been suggested as susceptibility genes for TLE.

There has been a reported increased risk of TLE in those with a family history of seizures with polymorphisms of the prodynorphin gene, which encodes dynorphin (anticonvulsant peptide), a strong candidate for a seizure suppressor gene, ${ }^{36}$ which has not been reproduced by other investigators. ${ }^{37}$

Polymorphisms of interleukin- $1 \beta$ (IL$1 \beta)$, IL- $1 \alpha$, and IL- 1 receptor antagonist genes have been studied, which encode proinflammatory cytokines that modulate neurotoxic neurotransmitters. Functional polymorphisms in the IL- $1 \beta$ gene associated with TLE and hippocampal sclerosis have been described, ${ }^{38}$ but not reproduced by others. ${ }^{39} 40$ Polymorphisms of IL-1 receptor antagonist have been described in susceptibility to febrile convulsions, ${ }^{41}$ but not found by other investigators. ${ }^{38}$

Apolipoprotein E (APOE) $\epsilon 4$ allele, promotes deposition of $\beta$-amyloid, and evidence from animal studies suggest the brain's ability to repair damage is impaired by its presence, hence may result in an epileptogenic focus. ${ }^{42}{ }^{43} \mathrm{It}$ was found that the presence of APOE $€ 4$ allele may shorten latency between initial injury and seizure onset in $\mathrm{TLE}^{42}$ however associations between APOE polymorphism and TLE were not found in other studies. ${ }^{44} 45$

Polymorphisms of the GABA (B) receptor l gene, which encodes the major inhibitory neurotransmitter in the CNS, have been studied and an association between the G1465A polymorphism and increased susceptibility to TLE was recently described ${ }^{46}$ To date, this is the only published study of this association.

We are only beginning to understand the genetics of TLE. Our traditional understanding was that it was an acquired condition, but only now are we beginning to understand the extent of genetic contribution to this condition. In the future we need to continue to find large families to perform linkage analysis in order to determine further candidate genes as well as continue the search for susceptibility genes through association studies.

J Neurol Neurosurg Psychiatry

2003;74:1359-1361

\section{Author's affiliation}

L Vadlamudi, I E Scheffer, S F Berkovic, Epilepsy Research Institute, University of Melbourne, Australia

Competing interests: none declared

Correspondence to: Professor S Berkovic, Epilepsy Research Institute, University of Melbourne, Austin Health, First Floor, Neurosciences Building, Banksia Street, Heidelberg West, VIC 3081, Australia; s.berkovic@unimelb.edu.au 


\section{REFERENCES}

1 Horsley V. Brain-surgery. BMJ 1886;ii:670-5.

2 Jackson $\mathbf{H}$. On a particular variety of epilepsy ("intellectual aura"), one case with symptoms of organic brain disease. Brain 1888;11:179-207.

3 Gibbs FA, Gibbs EL, Lennox WG. Epilepsy: a paroxysmal cerebral dysrhythmia. Brain 1937;60(4):377-88

4 Jasper H, Kershman J. Electroencephalographic classification of the epilepsies. Archives of Neurology and Psychiatry 1941:45:903-43.

5 Bruton CJ. The neuropathology of temporal lobe epilepsy. Oxford: Oxford University Press, 1988.

6 Falconer MA, Serafetinides EA, Corsellis JAN Etiology and pathogenesis of temporal lobe epilepsy. Arch Neurol 1964; 10:233-48

7 Ottman R, Risch N, Hauser WA, et al. Localization of a gene for partial epilepsy to chromosome 10q. Nat Genet 1995; 10:56-60.

8 Winawer M, Ottman R, Hauser WA, et al. Autosomal dominant partial epilepsy with auditory features: defining the phenotype. Neurology 2000;54:2173-6.

9 Poza JJ, Saenz A, Martinez-Gil A, et al. Autosomal dominant lateral temporal epilepsy: clinical and genetic study of a large Basque pedigree linked to chromosome 10q. Ann Neurol 1999;42(2): 182-8.

10 Brodtkorb E, Gu W, Nakken KO, et al. Familial temporal lobe epilepsy with aphasic seizures and linkage to chromosome 10q22-q24. Epilepsia 2002;43(3):228-35.

11 Kalachikov S, Evgrafov O, Ross B, et al Mutations in LGI1 cause autosomal-dominant partial epilepsy with auditory features. Nat Genet 2002;30(3):335-41

12 Morante-Redolat JM, Gorostidi-Pagola A, Piquer-Sirerol, et al. Mutations in the LGI1/ Epitempin gene on 10q24 cause autosomal dominant lateral temporal epilepsy. Hum Mol Genet 2002;11(9): 111 19-28.

13 Bissulli F, Tinuper P, Marini C et al. Partial epilepsy with prominent auditory symptoms not linked to chromosome 10q. Epileptic Disorders 2002;3: 183-7.

14 Pizzuti A, Flex E, Di Bonaventura C, et al. Epilepsy with auditory features: a LGI1 gene mutation suggests a loss-of-function mechanism. Ann Neurol 2003:53:396-9.

15 Kullmann DM. Genetics of epilepsy. J Neurol Neurosurg Psychiatry 2002;73(Suppl II):ii32-ii35.

16 Berkovic SF, Howell A, Hopper JL. Familial temporal lobe epilepsy: a new syndrome with adolescent/adult onset and a benign course. In: Wolf $\mathrm{P}$, ed. Epileptic seizures and syndromes. London: John Libbey \& Company Ltd, 1994:257-63.
17 Berkovic SF, Mclntosh A, Howell A, et al. Familial temporal lobe epilepsy: a common disorder identified in twins. 1996:40:227-35.

18 Aguglia U, Gambardella A, Le Piane E, et al. Mild non-lesional temporal lobe epilepsy a common, unrecognized disorder with onset in adulthood. Can J Neurol Sci 1998;25(4):282-6.

19 Regesta G, Tanganelli P. Temporal lobe epilepsy of adult age of possible idiopathic nature. Seizure 2002;11(2):131-5.

20 Gambardella A, Messina D, Le Piane E, et al. Familial temporal lobe epilepsy Autosomal dominant inheritance in a large pedigree from Southern Italy. Epilepsy Res 2000;38:127-32.

21 Brewster Smith W, So N, Thompson K. Familial temporal lobe epilepsy. Epilepsia 1996;37(Suppl. 5):34.

22 Cendes F, Lopes-Cendes I, Andermann E, et al. Familial temporal lobe epilepsy: a clinically heterogeneous syndrome. Neurology 1998;50:554-7.

23 Kobayashi E, Lopes-Cendes I, Guerreiro CAM, et al. Seizure outcome and hippocampal atrophy in familial mesial temporal lobe epilepsy. Neurology 2001;56: 166-72

24 Mathern GW, Babb TL, Vickrey BG, et al. The clinical-pathogenic mechanisms of hippocampal neuron loss and surgical outcomes in temporal lobe epilepsy. Brain 1995;118:105-18.

25 Kalviainen R, Salmenpera T, Partanen K, et al Recurrent seizures may cause hippocampa damage in temporal lobe epilepsy. Neurology 1998:50:1377-82.

26 Fernandez G, Effenberger $O$, Vinz B, et al. Hippocampal malformation as a cause of familia febrile convulsions and subsequent hippocampal sclerosis. Neurology 1998;50:909-17.

27 Depondt C, Van Paesschen W, Matthijs G, et al Familial temporal lobe epilepsy with febrile seizures. Neurology 2002;58:1429-33.

28 Baulac S, Picard F, Herman A, et al. Evidence for digenic inheritance in a family with both febrile convulsions and temporal lobe epilepsy implicating chromosomes 18gter and 1q25-q31. Ann Neurol 2001:49.786-92.

29 Ward N, Evanson J, Cockerell OC. Idiopathic familial temporal lobe epilepsy with febrile convulsions. Seizure 2002;11(1):16-19.

30 Maher J, McLachlan RS. Febrile convulsions. Is seizure duration the most important predictor of temporal lobe epilepsy? Brain 1995; 118:1521-28

31 Abou-Khalil B, Ge Q, Desai R, et al. Partial and generalized epilepsy with febrile seizures plus and a novel SCN1A mutation. Neurology 2001;57(12):2265-72.

32 Scheffer IE, Phillips HA, O'Brien CE, et al. Familial partial epilepsy with variable foci: a new partial epilepsy syndrome with suggestion of linkage to chromosome 2. Ann Neurol 1998;44(6):890-9.
33 Xiong L, Labuda M, Li D-S, et al. Mapping of a gene determining familial partial epilepsy with variable foci to chromosome $22 q 11-q 12$. Am J Hum Genet 1999;65(6):1698-1710.

34 Kinton L, Johnson MR, Smith SJ, et al. Partial epilepsy with pericentral spikes: a new familial epilepsy syndrome with evidence for linkage to chromosome 4p15. Ann Neurol 2002;51(6):740-9.

35 Botstein D, Risch N. Discovering genotypes underlying human phenotypes: past successes for mendelian disease, future approaches for complex disease. Nat Genet Supplement 2003;33:228-237.

36 Stogmann E, Zimprich A, Baumgartner C, et al. A functional polymorphism in the prodynorphin gene promotor is associated with temporal lobe epilepsy. Ann Neurol 2002;51:260-3.

37 Tilgen N, Rebstock J, Horvath S, et al. Prodynorphin gene promoter polymorphism and temporal lobe epilepsy. Ann Neurol 2003:53(2):280-2.

38 Kanemoto K, Kawasaki J, Miyamoto T, et al. Interleukin (IL) $1 \beta$, IL- $1 \alpha$, and IL-1 receptor antagonist gene polymorphisms in patients with temporal lobe epilepsy. Ann Neurol 2000:47(5):571-4.

39 Buono RJ, Ferraro TN, O'Connor MJ, et al. Lack of association between an interleukin 1 beta (IL$1 \beta$ ) gene variation and refractory temporal lobe epilepsy. Epilepsia 2001;42(6):782-4.

40 Heils A, Haug K, Kunz WS, et al. Interleukin-1 $\beta$ gene polymorphism and susceptibility to temporal obe epilepsy with hippocampal sclerosis. Ann Neurol 2000:48(6):948-50.

41 Tsai F-J, Hsieh Y-Y, Chang C-C, et al. Polymorphisms for interleukin $1 \beta$ exon 5 and interleukin 1 receptor antagonist in Taiwanese children with febrile convulsions. Arch Pediatr Adolesc Med 2002;156:545-8.

42 Briellmann RS, Torn-Broers Y, Busuttil BE, et al. APOE e4 genotype is associated with an earlier onset of chronic temporal lobe epilepsy. Neurology 2000;55:435-7.

43 Poirier J. Apolipoprotein E in animal models of CNS injury and in Alzheimer's disease. Trends Neurosci 1994:17:525-30.

44 Bluemcke I, Brockhaus A, Scheiwe C, et al. The apolipoprotein E epsilon 4 allele is not associated with early onset temporal lobe epilepsy. Neuroreport 1997;8:1235-37.

45 Gambardella A, Aguglia U, Cittadella R, et al. Apolipoprotein E polymorphisms and the risk of nonlesional temporal lobe epilepsy. Epilepsia 1999;40(12):1804-07.

46 Gambardella A, Manna I, Labate A, et al. $\mathrm{GABA}(\mathrm{B})$ receptor 1 polymorphism $(\mathrm{G} 1465 \mathrm{~A})$ is associated with temporal lobe epilepsy. Neurology 2003;60:560-3.

\section{Enteroviruses in chronic fatigue syndrome: "now you see them, now you don' $t^{\prime \prime}$}

\section{C Dalakas}

Can enteroviruses infect human muscle and cause persistent infection that affects only the metabolic machinery of the cells without muscle destruction? $\mathrm{n}$ the paper by Lane et al (see pp 13821386 $)^{1}$ an association was found between abnormal exercise lactate response and enterovirus sequences in the muscle of some patients with chronic fatigue syndrome (CFS). The paper rekindles the old saga of enteroviruses, muscle inflammation, and fatigue.

CFS remains an elusive entity. When all known factors causing fatigue are excluded, a number of patients have organic disease. Because some CFS patients have impaired muscle energy metabolism, ${ }^{2}$ the cause of fatigue may not be "in their head" but "in their muscle". Now, Lane et al propose that 
such metabolic impairment is more common in patients with enteroviral sequences in the muscle. The paper raises a fundamental question: can enteroviruses infect human muscle and cause persistent infection that affects only the metabolic machinery of the cells without muscle destruction? If so, is this clinically relevant to CFS patients?

Although coxsackieviruses in mice cause acute myositis, there is no convincing evidence that they also infect human muscle. ${ }^{3}$ Cases of epidemic pleurodynia, myoglobinuria, or myocarditis attributed to coxsackieviruses, remain unsubstantiated. The evidence is even weaker for chronic diseases, such as CFS or inflammatory myopathies. ${ }^{3}$ Unfortunately, the application of modern molecular virology techniques have not cleared the field; instead, they keep the controversy alive. Furthermore, data on viral persistence emerging from the mouse model and tissue cultures, fuel the scientific interest. After an acute enteroviral infection, mice develop a chronic, $\mathrm{T}$ cell dependent, myositis; viral RNA is detectable in the muscle but declines over a 12 month period, as the inflammation resolves. Non-dividing cells, such as myofibres, if survived the acute cytopathic damage, regenerate and may harbour viral RNA, trapped in the cytoplasm. ${ }^{3}$ These viral material mutate, become less lytic or infective and under certain conditions, may produce interferon or other cell mediators that upregulate transcription of cytokine genes through activation of nuclear factor kappa B (NFкB). The induced nitric oxide synthase and cytokines, such as tumour necrosis factor alpha or interleukin 1, may either cause a slow muscle fibre injury or deprive the cells of their luxury functions, resulting in indolent metabolic dysfunction. ${ }^{34}$

Accordingly, the findings of Lane et al are theoretically relevant to CFS even though a causal relationship between viral persistence and reduced muscle endurance was not demonstrated. In the past, such findings have turned out to be epiphenomena because enteroviruses are ubiquitous in humans and technical flaws inherently connected to contamination in laboratories working with these viruses are inevitable. Lane et al have performed a careful study and their findings deserve attention because, if proved to be specific, they will provide the first indirect indication of a viral related fatigue in a subset of CFS patients.

CFS is a common problem and any clues regarding its cause are welcome. The authors need, however, to demonstrate enterovirus within the muscle fibres by in situ PCR; prove that viral persistence alters the metabolic machinery of the cell; and show that such abnormalities cause clinical symptomatology. This is a laborious, but worthwhile effort that may prove rewarding for the millions of CFS patients because anti-enteroviral agents are now available (pleconaril) or in the offing. The authors may be on the right target but there are no shortcuts in pursuing it.

\section{J Neurol Neurosurg Psychiatry \\ 2003;74:1361-1362}

\section{Author's affiliation}

M C Dalakas, Neuromuscular Diseases Section, National Institute of Neurological Disorders and Stroke, National Institutes of Health, Bethesda, Building 10, Room 4N248, 10 Center Dr. MSC 1382, MD 20892-1382, USA

Correspondence to: $\operatorname{Dr}$ M C Dalakas; dalakasm@ninds.nih.gov

\section{REFERENCES}

1 Lane RJM, Soteriou BA, Zhang $H$, et al. Enterovirus related metabolic myopathy: a postviral fatigue syndrome. J Neurol Neurosurg Psychiatry 2003; 74:1382-6.

2 McCully KK, Natelson BH, lotti S, et al. Reduced oxidative muscle metabolism in chronic fatigue syndrome. Muscle Nerve 1996;19:621-5.

3 Dalakas MC. Viral related muscle disease. In: Engel AG, ed. Myology. New York: McGraw Hill, 2003 (in press)

4 Pelletier I, Duncan G, Pavio N, et al. Molecular mechanisms of poliovirus persistence: key role of capsid determinants during the establishment phase. Cell Mol Life Sci 1998;54:1385-1402.

\section{Multicentre European study of thalamic stimulation in essential tremor}

\section{J P R Dick}

Bilateral thalamic deep brain stimulation continues to show well maintained benefit in patients who have severe essential tremor after seven years with little increase in stimulation parameters

I n their paper, Sydow et al (see this issue pp 1387-1391) ${ }^{1}$ have shown sustained long term efficacy of high frequency deep brain stimulation of the thalamus (Vim) for the management of severe essential tremor. This observation is of interest as certain authors had commented that its benefit may wane with time. ${ }^{2}$

A multicentre European trial had initially demonstrated the efficacy of thalamic deep brain stimulation (largely unilateral) in the management of essential tremor $^{3}$ and a subsequent comparison of bilateral Vim stimulation with unilateral thalamotomy suggested that deep brain stimulation was more effective and certainly associated with fewer side effects. ${ }^{4}$ In the latter study the outcome was slightly better for essential tremor patients (using either procedure) than for patients with Parkinson's disease or multiple sclerosis. At 6 months some tremor had recurred in 7 of 34 patients ( 3 Parkinson's disease, 4 multiple sclerosis) undergoing unilateral thalamotomy and in 3 of 34 (1 Parkinson's disease, 2 multiple sclerosis) undergoing bilateral deep brain stimulation; no tremor had returned in any of the 13 patients with essential tremor. The greater efficacy of bilateral thalamic deep brain stimulation for essential tremor is highlighted by Deuschl et al in their review. ${ }^{5}$ They comment that a bilateral procedure may have additional benefit for tremor of mid-line structures. ${ }^{5}$

In this study, 37 essential tremor patients managed with bilateral thalamic deep brain stimulation were reviewed after one and six years. While there was a non-significant trend towards increased tremor after six years, an excellent functional improvement was still maintained when comparing both activities of daily living and tremor scores, ON and OFF stimulation. This trend would, of course, be consistent with the natural history of essential tremor. The observed increase in stimulator output during the six year period largely arose in the first year (2.0 to $2.3 \mathrm{~V})$. The authors speculate that the subsequent increase ( 2.3 to $2.6 \mathrm{~V}$ ) was a reflection of disease progression, although acknowledge that it may have reflected an element of tolerance. 
They quote only one other study with a follow up period of equivalent length. $^{6}$ In that study, 19 essential tremor patients were followed for six to seven years after unilateral thalamic deep brain stimulation. The benefits for postural and action tremor were well maintained over 6.5 years (SD $0.3)$ although, again, some slippage of effect was seen, for example for action tremor of the legs. The stimulator output increased from $2.0 \mathrm{~V}$ (SD 0.7), initially to $2.4 \mathrm{~V}$ (SD 0.9 ) after two years, and was $2.3 \mathrm{~V}$ (SD 1.0) after six to seven years.

These and other studies have shown that unilateral deep brain stimulation is as effective as unilateral thalamotomy in the management of severe essential tremor and it may be that bilateral deep brain stimulation is better than unilateral deep brain stimulation, particularly for those with a generalised tremor syndrome. Had there been poor dur- ability of long term deep brain stimulation, the marginal superiority of stimulation over thalamotomy would have been lost, especially considering the cost and the more intense follow up regime required for deep brain stimulation. However, these two long term studies show well maintained symptomatic benefit over six to seven years, and any trend for recurrent tremor was scarcely detectable by statistics and may reflect the natural progression of the disease.

J Neurol Neurosurg Psychiatry 2003:74:1362-1363

\section{Author's affiliation}

J P R Dick, Department of Neurology, Greater Manchester Neuroscience Centre, Hope Hospital, Stott Lane, Salford M6 8HD, UK

Correspondence to: DR J P R Dick; Jeremy.Dick@srht.nhs.uk
Competing interests: JPRD was sponsored by Medtronic to attend a two day workshop organised by the European Continuing Medical Training Group, on deep brain stimulation in Keil, Germany, January 2003

\section{REFERENCES}

1 Sydow O, Thobois S, Alesch F, et al. Multicentre European study of thalamic stimulation in essential tremor: a six year follow up. J Neurol Neurosurg Psychaitry 2003:74:1387-91.

2 Benabid AL, Pollak P, Hoffman D, et al. Chronic high frequency stimulation in Parkinson's disease. In: Koller WC, Paulson GW, eds. Therapy of

Parkinson's disease, 2nd edn. New York: Marcel Dekker, 1994:381-482

3 Limousin P, Speelman JD, Gielen F, et al. Multicentre European study of thalamic stimulation in parkinsonian and essential tremor. I Neuro Neurosurg Psychiatry 1999:66:289-96.

4 Schuurman PR, Bosch DA, Bossuyt PMM, et al. A comparison of continuous thalamic stimulation and thalamotomy for suppression of severe tremor. New Engl J Med 2000;342:461-8.

5 Deuschl G, Wenzelburger R, Raethien J. Tremor: a review. Curr Opin Neurol 2000;13:437-43.

6 Rehncrona S, Johnels B, Widner H, et al. Long Term (6-7 years) efficacy of thalamic DBS for tremor: double blind assessments. Mov Dis 2003;18:171-5.

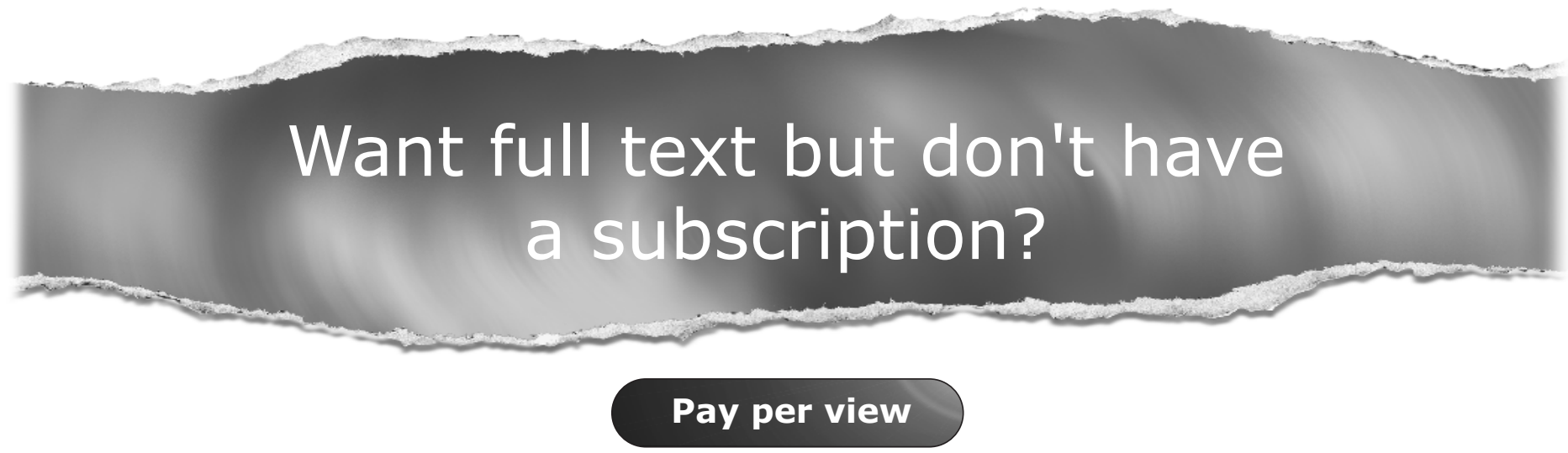

For just $\$ 8$ you can purchase the full text of individual articles using our secure online ordering service. You will have access to the full text of the relevant article for 48 hours during which time you may download and print the pdf file for personal use.

www.jnnp.com 